\title{
PENGARUH METODE EKSPERIMEN TERHADAP KONSENTRASI ANAK BERKEBUTUHAN KHUSUS DALAM PEMBELAJARAN SAINS
}

\author{
Diana Khamidun \& Elif Mauzidatuf Khoiroh \\ e-mail: diana_paud99@yahoo.co.id \\ Pendidikan Luar Biasa, FIP Universitas Negeri Semarang
}

\begin{abstract}
Abstrak: Penelitian ini bertujuan untuk memberikan informasi dan gambaran yang tepat tentang pengaruh metode eksperimen terhadap konsentrasi anak berkebutuhan khusus dalam pembelajaran sains awal. Penelitian ini diselenggarakan di Taman Latihan dan Observasi Sekolah Luar Biasa di Kota Semarang, pada kelompok anak usia dini usia 2-5 tahun dengan menggunakan 14 anak. Untuk melihat pengaruh metode eksperimen terhadap konsentrasi anak berkebutuhan khusus, penelitian ini menggunakan eksperimen untuk memberikan perlakuan kepada kelompok eksperimen. Hipotesis penelitian diuji dengan menggunakan uji-t. Hasil penelitian menjunjukkan, metode eksperimen dapat memberikan pengaruh yang signifikan terhadap konsentrasi anak berkebutuhan khusus dalam pembelajaran sains awal. Metode eksperimen sebagai suatu metode belajar yang dipergunakan di kelas pra sekolah di lembaga pengembangan anak usia dini, tempat anak berkebutuhan khusus belajar, dapat membengaruhi kemampuan/konsentrasi mereka dalam belajar, khususnya sains awal. Metode ini memberikan anak kesempatan mengetahui dan berinteraksi dengan lingkungan.
\end{abstract}

Kata kunci: metode eksperimen, konsentrasi, anak berkebutuhan khusus, sains awal

\section{THE INFLUENCE OF EXPERIMENTAL METHODS TOWARDS CONCENTRATION IN EARLY CHILDHOOD DISABILITIES IN LEARNING MATERIALS OF BEGINNING SCIENCE}

\begin{abstract}
The research objective is to provide accurate information and picture about the influence of the experimental method to the concentration of children with disabilities in beginning science activities. The research was carried out in the Training Park and Observation of Foreign School in Semarang, with a total sample 14 early age children with special needs. This study used an experimental design providing a group with treatment to see the influence. T-test was used to prove the hypothesis that the experimental method can have a significant influence on the concentration of children with disabilities to learn beginning science. Experimental method as a learning method in preschool classes in the institution of early childhood development, can influence the children's ability/concentration in learning. This method gives children the opportunity to know and interact with the environment and enable them to focus and concentrate on learning activities in the classroom.
\end{abstract}

Keywords: experimental method, concentration, early childhood disabilities, beginning science.

\section{PENDAHULUAN}

\section{Latar Belakang}

Anak merupakan subyek dalam pembelajaran sains. Merekalah yang menjadi pengamat dan peneliti muda dalam sains. Pemenuhan kebutuhan dalam sains untuk anak usia dini harus disesuaikan dengan pertumbuhan dan perkembangan anak berdasarkan rentang usia anak 0-8 tahun. Pada dasarnya aspekaspek perkembangan anak adalah merupakan hal-hal yang turut tumbuh dan berkembang dalam seluruh diri anak. Perkembangan anak yang satu dengan yang lain tentulah berbeda, begitu halnya bagi anak-anak berkebutuhan khusus. Mereka memiliki karakteristik yang sangat berbeda dengan anak-anak yang normal pada umumnya. Namun hal ini bukanlah menjadi kendala bagi mereka untuk dapat mempelajari berbagai ilmu pengetahuan, terutama sains.

Pembelajaran sains pada hakikatnya merupakan pembelajaran yang memberikan pengetahuan pada anak tentang dunia disekitar mereka. Lingkungan yang menjadi tempat tinggal mereka merupakan 
bagian dalam pembelajaran sains. Anak diajak untuk bisa mengamati apa yang ada dilingkungan serta perubahan-perubahan yang terjadi dilingkungannya. Hal-hal yang sederhana yang terjadi dilingkungan merupakan pembelajaran sains bagi anak. Anak diajak untuk bisa mengamati apa yang ada dilingkungan serta perubahan-perubahan yang terjadi dilingkungannya. Hal-hal yang sederhana yang terjadi dilingkungan merupakan pembelajaran sains bagi anak. Anak berkebutuhan khusus memiliki kesempatan yang sama untuk dapat menjadi peneliti yang baik dengan segala kekurangan yang mereka miliki.

Kegiatan Sains dapat dilakukan dengan berbagai cara sesuai dengan kemampuan guru dalam menyampaikan. Namun, pada dasarnya kegiatan ini dilakukan dengan melakukan percobaan-percobaan atau eksperimen. Untuk anak usia dini kegiatan eksperimen yang dilakukan sifatnya masih sederhana dan dengan memanfaatkan lingkungan sebagai sumber belajar. Anak melakukan pengamatan dan percobaan dari hal-hal yang sederhana yang biasa mereka dapati dilingkungan sekitar.

Namun pada kenyataan dilapangan, bagi guruguru yang menangani anak dengan berkebutuhan khusus masih mengalami kesulitan untuk mengaplikasikan kegiatan sains agar mudah diterima oleh anak. Anak usia dini dengan kebutuhan khusus memerlukan pembelajaran dan perhatian yang khusus agar anak dapat memiliki konsentrasi dan fokus dengan materi kegiatan yang diberikan oleh gurunya. Berdasarkan hasil pengamatan dari 20 siswa dikelas berkebutuhan khusus yang mampu dan memiliki konsentrasi yang baik saat guru memberikan penjelasan hanya sekitar $40 \%$ saja. Hal ini dikarenakan keterbatasan yang masing-masing anak miliki, sehingga guru berusaha agar mereka dapat fokus apa yang dijelaskan oleh gurunya.

Berdasarkan latar belakang diatas, maka perumusan masalah pada penelitian ini adalah sebagai berikut: " Apakah terdapat pengaruh metode eksperimen terhadap konsentrasi anak berkebutuhan khusus dalam materi pembelajaran sains di Taman Latihan dan Observasi SLB Negeri Semarang?"

\section{Kajian Teori}

\section{Metode Eksperimen}

Salah satu metode pembelajaran yang dapat digunakan dalam kegiatan pembelajaran bagi anak usia dini adalah metode percobaan (experimental methode). Metode percobaaan adalah metode eksperimen adalah metode pemberian kesempatan kepada anak didik perorangan atau kelompok untuk dilatih melakukan suatu proses atau percobaan. Syaful Bahri Djamarah (2000), metode eksperimen adalah suatu metode mengajar yang menggunakan perlakuan tertentu dan dilakukan lebih dari satu kali, misalnya di laboratorium.

Kelebihan metode eksperimen sebagai berikut. Pertama, metode ini dapat membuat anak didik lebih percaya atas kebenaran atau kesimpulan berdasarkan percobaannya sendiri daripada hanya menerima kata guru atau buku. Kedua, anak didik dapat mengembangkan sikap untuk mengadakan studi eksplorasi (menjelajahi) tentang ilmu dan teknologi. Ketiga, dengan metode ini akan terbina manusia yang dapat membawa terobosan-terobosan baru dengan penemuan sebagai hasil percobaan yang diharapkan dapat bermanfaat bagi kesejahteraan hidup manusia.

Sedangkan kekurangan metode percobaan antara lain, Pertama, tidak cukupnya alat-alat mengakibatkan tidak setiap anak didik berkesempatan mengadakan eksperimen. Kedua, jika eksperimen memerlukan jangka waktu yang lama, anak didik harus menanti untuk melanjutkan pelajaran. Ketiga, metode ini lebih sesuai untuk menyajikan bidang-bidang ilmu dan teknologi.

Menurut Roestiyah dalam Soekamto (1997) metode eksperimen adalah suatu cara mengajar, dimana siswa melakukan suatu percobaan tentang sesuatu hal, mengamati prosesnya serta menuliskan hasil percobaannya, kemudian hasil pengamatan itu disampaikan didepan kelas dan dievaluasi oleh guru.

Penggunaan teknik ini mempunyai tujuan agar siswa mampu mencari dan menemukan sendiri berbagai jawaban atau persoalan-persoalan yang dihadapinya dengan mengadakan percobaan sendiri. Juga siswa dapat terlatih dalam cara berfikir yang ilmiah. Dengan eksperimen siswa menemukan bukti kebenaran dari teori sesuatu yang sedang dipelajarinya.

Agar penggunaan metode eksperimen itu efisien dan efektif, maka perlu diperhatikan hal-hal sebagai berikut : (a) Dalam eksperimen setiap siswa harus mengadakan percobaan, maka jumlah alat dan bahan atau materi percobaan harus cukup bagi tiap siswa. (b) Agar eksperimen itu tidak gagal dan siswa menemukan bukti yang meyakinkan, atau mungkin hasilnya tidak membahayakan, maka kondisi alat dan mutu bahan percobaan yang digunakan harus baik dan bersih. (c) dalam eksperimen siswa perlu teliti dan konsentrasi dalam mengamati proses percobaan , maka perlu adanya waktu yang cukup lama, sehingga mereka menemukan pembuktian kebenaran dari teori yang dipelajari itu. (d) Siswa dalam eksperimen 
adalah sedang belajar dan berlatih , maka perlu diberi petunjuk yang jelas, sebab mereka disamping memperoleh pengetahuan, pengalaman serta ketrampilan, juga kematangan jiwa dan sikap perlu diperhitungkan oleh guru dalam memilih obyek eksperimen itu. (e) Tidak semua masalah bisa dieksperimenkan, seperti masalah mengenai kejiwaan, beberapa segi kehidupan sosial dan keyakinan manusia. Kemungkinan lain karena sangat terbatasnya suatu alat, sehingga masalah itu tidak biasa diadakan percobaan karena alatnya belum ada.

Penerapan pembelajaran dengan menggunakan metode eksperimen akan membantu siswa untuk memahami konsep. Pemahaman konsep dapat diketahui apabila siswa mampu mengutarakan secara lisan, tulisan, maupun aplikasi dalam kehidupannya. Dengan kata lain, siswa memiliki kemampuan untuk menjelaskan, menyebutkan, memberikan contoh, dan menerapkan konspe terkait dengan pokok bahasan.

\section{Pembelajaran Sains}

Konsep tentang sains yang bersifat standar dan dapat diterima oleh semua fihak sulit di kemukakan, tetapi batasan-batasan yang bersifat mendasar (subtansi) dapat dimunculkan dari berbagai dimensi. Dari sudut bahasa, sains atau Science (Bahasa Inggris), berasal dari Bahasa Latin, yaitu dari kata Scientia artinya pengetahuan. Para ahli memandang batasan etimologis yang tepat tentang sains yaitu dari bahasa Jerman, hal itu dengan merujuk pada kata Wissenschaft, yang memiliki pengertian pengetahuan yang tersusun atau terorganisasikan secara sistematis.

Secara konseptual terdapat sejumlah pengertian dan batasan sains yang dikemukakan oleh para ahli. Amien (1987), mendefinisikan sains sebagai bidang ilmu alamiah, dengan ruang lingkup zat dan energi, baik yang terdapat pada mahluk hidup maupun tak hidup, lebih banyak mendiskusikan tentang alam (natural science) seperti fisika, kimia dan biologi. Senada dengan Conant (Abu Ahmadi,1991) memberikan pengertian sains sebagai ilmu teoritis yang didasarkan atas pengamatan, percobaan-percobaaan terhadap gejala alam berupa makrokosmos (alam semesta) dan mikrokosmos (isi alam semesta yang lebih terbatas, khususnya tentang manusia dan sifat-sifatnya).

Secara umum, Mustaffa (2002) mengidentifikasi sejumlah karakteristik dari anak usia dini. Pertama, menggunakan semua indrera untuk menjelajahi benda, belajar melalui kegiatan motorik dan partisipasi sosial. Kedua, rentang perhatiannya masih pendek, mudah bosan dan mudah beralih apabila ada yang baru. Ketiga, mulai mengembangkan dasar-dasar keterampilan berbahasa, bermain-main dengan bunyi, mempelajari kosa kata dasar dengan konsep-konsepnya, mulai mempelajari aturan yang bersifat implisit yang mengatur ekspresinya. Keempat, perkembangan bahasa yang pesat. Kelima, aktif memperhatikan segala sesuatu tetapi dengan rentang atensi yang pendek. Keenam, menempatkan diri sebagai pusat dunianya sendiri, minat perilaku dan pikiran yang terpokus pada diri (egosentris). Ketujuh, serba ingin tahu tentang dunianya sendiri sebagai kanak-kanak. Kedelapan, mulai tertarik dengan bagaimana mekanisme kerja berbagai hal dan dunia luar di sekitarnya.

Dengan memperhatikan kedua faktor yang sama pentingnya dan harus diperhatikan dalam pembelajaran sains, maka diperlukan kemampuan pendidik atau guru atau orang dewasa lainnya yang memberikan pembelajaran kepada anak usia dini, dalam hal membuat perencanaan pembelajaran dan melaksanakannya.

Dalam membuat perencanaan, ada beberapa unsur yang harus diperhatikan, yaitu merumuskan kompetensi dan indikator apa yang harus dimiliki oleh anak setelah pembelajaran diberikan, materi sains yang sesuai dengan indikator yang akan dicapai, bagaimana merumuskan kegiatan pembelajaran yang akan dilaksanakan dengan menyesuaikan karakteristik materi dengan karakteristik perkembangan anak serta usia anak, media apa yang tepat dan tersedia dan akan digunakan dalam proses pembelajaran, dalam memilih media ini tidak cukup satu jenis media yang digunakan, melainkan multi media, karena mengingat karakteristik perkembangan anak usia dini (mudah bosan, hanya bisa fokus pada waktu yang pendek dan mudah berpaling dari objek lain apabila tidak menarik), unsur yang terakhir adalah merumuskan asesmen yang akan digunakan dalam pembelajaran, untuk mengetahui sejauhmana perkembangan anak dari materi yang disajikan.

Sedangkan dalam melaksanakan pembelajaran, guru dituntut melaksanakan semua rencana yang sudah didesain sedemikian rupa pada tahap perencanaan sebelumnya, dengan disertai antusias, kesungguhan dan langkah-langkah yang dilakukan dengan mengacu pada bermain seraya belajar dalam memberikan pengalaman pada anak.

\section{Anak Berkebutuhan Khusus}

Anak berkebutuhan khusus (Heward) adalah anak dengan karakteristik khusus yang berbeda dengan anak pada umumnya tanpa selalu menunjukan pada ketidakmampuan mental, emosi atau fisik. Yang termasuk kedalam ABK antara lain: tunanetra, tunarungu, tunagrahita, tunadaksa, tunalaras, kesulitan belajar, gangguan prilaku, anak berbakat, anak 
dengan gangguan kesehatan. istilah lain bagi anak berkebutuhan khusus adalah anak luar biasa dan anak cacat. Karena karakteristik dan hambatan yang dimilki, ABK memerlukan bentuk pelayanan pendidikan khusus yang disesuaikan dengan kemampuan dan potensi mereka, contohnya bagi tunanetra mereka memerlukan modifikasi teks bacaan menjadi tulisan Braille dan tunarungu berkomunikasi menggunakan bahasa isyarat. Anak berkebutuan khusus biasanya bersekolah di Sekolah Luar Biasa (SLB) sesuai dengan kekhususannya masing-masing. SLB bagian A untuk tunanetra, SLB bagian B untuk tunarungu, SLB bagian C untuk tunagrahita, SLB bagian D untuk tunadaksa, SLB bagian $E$ untuk tunalaras dan SLB bagian $G$ untuk cacat ganda.

Anak berkebutuhan khusus dapat digolongkan dalam beberapa kategori. Pertama, keterbelakangan mental (tuna grahita).Gejala yang timbul pada umumnya nyata berupa keterlambatan hampir semua aspek perkembangan anak seperti perkembangan motorik kasar dan halus, kognitif, wicara-bahasa, sosial dan bantu diri. Contoh : anak sindrom Down, Mental retardasi.

Kedua, Sindrom Down Manifestasi Klinis wajah sangat khas dan tidak tergantung ras dengan ciri-ciri: wajah tampak datar; jembatan hidung yang lebar dan datar; garis mata cendrung miring keatas; lidah cendrung menjulur keluar, karena maksli kecil dan palatum sempit; telinga kecil dan letak rendah; sering diikuti gangguan refraksi mata; kepala berbentuk brakisefali dan kecil; jari tangan kelima biasanya melengkung dan pendek; garis simian; tangan lebar dan jari tangan pendek; terdapat celah lebar antara jari kaki I dan II; 40\% disertai kelainan jantung : VSD, ASD, PDA; kadang-kadang disertai atresia ani, atresia duodenum, hirschprung; retardasi mental bervariasi; keterlambatan perkembangan motor, adaptif, dan sosialisasi sebelum usia 1 tahun; pemeriksaan neurologis pada bayi : sering sulit minum dan apatik, hipotonia, refleks lambat, ikterus fisiologis yang memanjang; kejang berkisar antara 2 - 9\%; gangguang fungsi kel teroid pada beberapa pasien; serta tinggi badan biasanya kurang dari rata-rata.

Kriteria diognostik retardasi mental menurut DSM-IV-TR yaitu: (a) fungsi intelektual yang secara signifikan dibawah rata-rata. IQ kira-kira 70 atau dibawahnya pada individu yang dilakukan test IQ; (b) gangguan terhadap fungsi adaptif paling sedikit 2 misalnya komunikasi, kemampuan menolong diri sendiri, berumah tangga, sosial, pekerjaan, kesehatan dan keamanan; dan (c) onsetnya sebelum usia 18 tahun.

Ketiga, autisme. Gejala yang dijumpai adalah tidak adanya kontak mata, menyendiri, (sulit bersosialisasi), adanya perilaku yang stereotipik seperti terpaku pada objek tertentu (putaran kipas angin), menolak suatu perubahan, terlambat perkembangan bicara membeo, sulit berdialog, sering disertai hiperaktivitas. Kreteria diagnosis 299.00 gangguan autistic, enam atau lebih gejala (1), (2), dan (3), dengan paling sedikit 2 dari (1) dan 1 dari masing-masing (2) dan (3), yaitu: (1) gangguang kualitatif interaksi sosial, yang terlihat sebagai paling sedikit 2 dari gejala berikut: (a) gangguan yang jelas dalam perilaku non verbal (perilaku yang dilakukan tanpa bicara), misalnya kontak mata. Ekspresi wajah, posisi tubuh, dan mimik untuk mengatur interaksi sosial; (b) tidak bermain dengan teman seumurnya, dengan cara yang sesuai; (c) tidak berbagi kesenangan, minat atau kemampuan mencapai sesuatu hal dengan orang lain, misalnya tidak memperlihatkan mainan kepada orang tua, tidak menunjuk kesuatu benda yang menarik , tidak berbagi kesenangan dengan orang tua; dan (c) kurangnya interaksi sosial timbal balik misalnya: tidak berpartisipasi aktif dalam bermain, lebih senang bermain sendiri; (2) gangguan kualitatif komunikasi yang terlihat sebagai paling tidak satu dari gejala berikut: (a) keterlambatan atau belum dapat mengucapakan kata-kata berbicara, tanpa diserta usaha kompensasi dengan cara lain misalnya mimik dan bahasa tubuh; (b) bila dapat berbicara, terlihat gangguan kesanggupan memulai atau mempertahankan komunikasi dengan orang lain; (c) penggunaan bahasa yang streotipik dan berulang, atau bahasa tidak dapat di mengerti, (d) tidak adanya cara bermain yang bervariasi dan spontan, atau bermain meniru secara sosial yang sesuai dengan umur perkembangannya; dan (3) pola perilaku, minat, dan aktivitas yang terbatas, berulang dan tidak berubah (stereotipik), yang ditunjukan dengan adanya 2 dari gejala berikut: (a) minat yang terbatas, stereotipik, menetap dan abnormal dalam intensitas dan fokus; (b) keterikatan pada suatu ritual yang spesifik tetapi tidak fungsional secara kaku dan tidak fleksibel; (c) gerakan motorik yang stereotipik dan berulang, misalnya: flapping tangan dan jari, gerakan tubuh yang kompleks; dan (d) preokupasi terhadap bagian dari benda.

Keempat, keterlambatan atau fungsi abnormal pada keterampilan berikut, yang muncul sebelum umur 3 tahun: interaksi sosial, bahasa yang digunakan sebagai komunikasi sosial, serta bermain simbolik atau imajinatif.

Kelima, Attention Deficit Hiperaktivity Disorders (ADHD). Ciri-cirinya: (a) tidak bisa mempertahankan perhatian, mereka sangat mudah beralih, perhatiannya pada hal-hal disekitarnya, mudah bosan, kemampuan 
ingatan jangka pendek rendah; (b) impulsif: Ketidakmampuan untuk mengontrol diri, Mereka sering dicap anak yang agresif, tidak tahu aturan, suka merebut barang teman, tidak sabar menunggu; (c) hiperaktif: Efek hiperaktifitas ini menjadi lebih buruk karena gabungan dengan impulsifitas. Kondisi ini menyulitkan anak saat belajar, duduk tenang, mendengarkan guru, mengerjakan tugas; (d) tidak terpuaskan butuh stimulasi dan perhatian yang terus menerus, dan harus segera terpenuhi; (e) kurang mampu melakukan interaksi sosial, tidak mengerti cara berinteraksi dengan baik, sering berprilaku kasar dan menjengkelkan teman, sering mengatakan hal yang tidak tepat; (f) koordinasi motorik halus buruk, tulisan sulit dibaca, kesulitan mewarnai, dan mengikat tali sepatu; (g) tidak teratur, umumnya tidak terorganisir, tidak rapi berpakaian, mengurus alat sekolah, dan lain-lain, pelupa, senang menunda tugas; (h) self esteem rendah dikarenakan kegagalan yang terus menerus serta komentar orang sekitar tentang anak GPPH; dan (i) mengalami kesulitan belajar, termasuk kesulitan dalam membaca, menulis, bahasa, matematika, atau kombinasi. Dari tes intelegensi: prestasinya jauh dibawah potensi yang dimiliki.

Keenam, cerebral palsy (CP), adalah suatu gangguan atau kelainan yang terjadi pada suatu kurun waktu dala perkembangan anak, mengenai sel-sel motorik didalam saraf pusat, bersifat kronik dan tidak progresif akibat kelainan atau cacat pada jaringan otak yang belum selesai pertumbuhannya. Gambaran klinis CP (a) paralisis: kelumpuhan dapat berupa: flacid (layuh), spastic (kaku), dapat berbentuk hemiplegi (separuh badan kanan/kiri), quariplegi (empat anggota gerak), diplegi (dua kaki), monoplegi (satu anggota gerak); (b) gerak involunter, yaitu gerakan yang tidak terarah dan tidak sesuai pola gerak; (c) ataxia, yaitu gangguan koordinasi karena kerusakan otak kecil, contohnya: jalannya lambat dan semua pergerakan menjadi canggung; (d) kejang, dapat bersifat umum (seluruh tubuh) atau fokal (satu bagian tubuh); dan (f) gangguan mental, ditemukan dari $1 / 3$ anak penderita $\mathrm{cp}$.

\section{METODE PENELITIAN}

Penelitian ini dilaksanakan di Sekolah Luar Biasa (SLB) di Kota Semarang dalam Agustus hingga Oktober 2012, pada kelompok anak usia dini usia 2-5 tahun. Populasi merupakan totalitas dari semua obyek atau individu yang memiliki karakteristik tertentu, jelas dan lengkap yang akan diteliti. Sesuai dengan pengertian tersebut, maka dalam penelitian ini yang dijadikan populasi adalah siswa berkebutuhan khusus di Sekolah Luar Biasa di Kota Semarang. Sampel adalah sebagaian dari jumlah dan karakteristik yang dimiliki oleh populasi (Sugiyono, 1997 : 56). Sutrisno Hadi (1980 : 70) mendefinisikan sampel sebagai bagian dari populasi yang diteliti atau diselidiki, dalam penelitian ini adalah anak usia dini di Taman Latihan dan Observasi, Sekolah Luar Biasa Negeri di Kota Semarang.
Teknik pengumpulan data dalam penelitian ini menggunakan non tes berupa skala, observasi, dan wawancara. Data yang terkumpul dianalisis dengan menggunakan analisis data kuantitatif dan yang nantinya juga dinarasikan dalam bentuk deskriptif, dimana hasil penelitian menggambarkan dan menjelaskan hasil penelitian yang dilakukan melalui skala, observasi dan wawancara tentang pengaruh metode eksperimen terhadap konsentrasi anak berkebutuhan khusus dalam materi pembelajaran sains. Adapun tahapantahapan yang sesuai dengan prosedur yang telah ditentukan, yaitu : pengumpulan data, reduksi data, display/atau penyajian data, dan verifikasi/penarikan kesimpulan.

\section{HASIL DAN PEMBAHASAN}

\section{Hasil Penelitian}

Data yang dianalisis dalam penelitian adalah data tentang kemampuan konsentrasi anak berkebutuhan khusus dalam materi pembelajaran sains yang dilakukan melalui metode eksperimen sederhana bagi anak-anak berkebutuhan khusus pada satu kelas eksperimen, yaitu di taman latihan dan observasi dengan jumlah siswa sebanyak 14 anak. Data ini diperoleh dari hasil pre-post tes pada satu kelas yang diberikan perlakuan berupa metode eksperimen.
Data dasar hasil penelitian dideskripsikan untuk memperoleh gambaran tentang karakteristik distribusi skor dari variabel penelitian. Deskripsi data penyajian skor tertinggi, skor terendah, rerata, standar deviasi, modus, dan media. Deskripsi data hasil hasil pre test dan post test kemampuan konsentrasi anak berkebutuhan khusus dalam materi pembelajaran sains dengan mengunakan metode eksperimen sederhana diuraikan pada tabel 1. 
Tabel 1. Tabulasi Data

\begin{tabular}{|c|c|c|c|c|}
\hline $\begin{array}{c}\text { No. } \\
\text { Resp. }\end{array}$ & $\begin{array}{c}\text { Pre Test } \\
(\mathrm{X} 1)\end{array}$ & $\begin{array}{c}\text { Post Test } \\
(\mathrm{X} 2)\end{array}$ & $\mathrm{X} 12$ & $\mathrm{X} 22$ \\
\hline 1 & 14 & 23 & 196 & 529 \\
\hline 2 & 12 & 17 & 144 & 289 \\
\hline 3 & 8 & 20 & 64 & 400 \\
\hline 4 & 14 & 19 & 196 & 361 \\
\hline 5 & 11 & 20 & 121 & 400 \\
\hline 6 & 15 & 15 & 225 & 225 \\
\hline 7 & 13 & 20 & 169 & 400 \\
\hline 8 & 16 & 22 & 256 & 484 \\
\hline 9 & 12 & 24 & 144 & 576 \\
\hline 10 & 13 & 22 & 169 & 484 \\
\hline 11 & 10 & 19 & 100 & 361 \\
\hline 12 & 9 & 18 & 81 & 324 \\
\hline 13 & 12 & 21 & 144 & 441 \\
\hline 14 & 10 & 19 & 100 & 361 \\
\hline $\mathrm{Jml}$ & 169 & 279 & 2109 & 5635 \\
\hline
\end{tabular}

Tabel 2 .Perhitungan Daftar Distribusi Pre-Test Konsentrasi Anak Berkebutuhan Khusus Materi Pembelajaran Sains

\begin{tabular}{|c|c|c|c|c|c|c|}
\hline No. & Skor & $f$ & $\begin{array}{l}\text { Batas } \\
\text { Atas }\end{array}$ & $\begin{array}{l}\text { Batas } \\
\text { Bawah }\end{array}$ & $\mathrm{fk}$ & $\mathrm{fr}$ \\
\hline 1 & $8-9$ & 2 & 7,5 & 9,5 & 2 & $14,3 \%$ \\
\hline 2 & $10-11$ & 3 & 9,5 & 11,5 & 5 & $21,4 \%$ \\
\hline 3 & $12-13$ & 5 & 11,5 & 13,5 & 10 & $35,7 \%$ \\
\hline 4 & $14-15$ & 3 & 13,5 & 15,5 & 13 & $21,4 \%$ \\
\hline 5 & $16-17$ & 1 & 15,5 & 17,5 & 14 & $7,1 \%$ \\
\hline \multicolumn{2}{|c|}{ Jumlah } & 14 & & & & $100 \%$ \\
\hline
\end{tabular}

Berdasarkan hasil deskripsi data dari tabel 2 , maka diperoleh skor terendah 8 dan skor tertinggi 16 , sehingga rentangnya dari rentang teoritik 0 sampai 100; skor rerata $=12,07 ;$ median $=12,30 ;$ modus $=$ 12,50; dan standar deviasi $=2,3027$. Data tersebut merupakan data hasil pre-test konsentrasi anak berkebutuhan pada materi pembelajaran sains dengan menggunakan metode eksperimen sederhana.

Tabel 3 .Perhitungan Daftar Distribusi Pos-Test Konsentrasi Anak Berkebutuhan Khusus Materi Pembelajaran Sains

\begin{tabular}{|c|c|c|c|c|c|c|}
\hline No. & Skor & $\mathrm{f}$ & $\begin{array}{c}\text { Batas } \\
\text { Atas }\end{array}$ & $\begin{array}{c}\text { Batas } \\
\text { Bawah }\end{array}$ & $\mathrm{fk}$ & $\mathrm{fr}$ \\
\hline 1 & $15-16$ & 1 & 14,5 & 16,5 & 1 & $7,1 \%$ \\
\hline 2 & $17-18$ & 2 & 16,5 & 18,5 & 3 & $14,3 \%$ \\
\hline 3 & $19-20$ & 6 & 18,5 & 20,5 & 9 & $42,9 \%$ \\
\hline 4 & $21-22$ & 3 & 20,5 & 22,5 & 12 & $21,4 \%$ \\
\hline 5 & $23-24$ & 2 & 22,5 & 24,5 & 14 & $14,3 \%$ \\
\hline \multicolumn{2}{|c|}{ Jumlah } & 14 & & & & $100 \%$ \\
\hline
\end{tabular}

Berdasarkan hasil deskripsi data pada tabel 3, diperoleh responden anak berkebutuhan khusus yang memiliki konsentrasi pada pembelajaran sains pada kelas rerata sebanyak 3 anak atau 42,9\%, responden anak berkebutuhan khusus yang memiliki konsentrasi pada pembelajaran sains dibawah rerata sebanyak 6 anak atau $21,4 \%$, dan responden anak berkebutuhan khusus yang memiliki konsentrasi pada pembelajaran sains di atas rerata sebanyak 5 anak atau 35,7\%.

Data variabel konsentrasi anak berkebutuhan pada materi pembelajaran sains dengan menggunakan metode eksperimen pada saat pre-test dan post test mengalami peningkatan yang signifikan. Peningkatan ini dipengaruhi oleh metode pembelajaran yang diberikan pada saat materi kegiatan pembelajaran sains. Peningkatan dari hasil pembelajaran dengan menggunakan metode eksperimen yang telah dilakukan dapat dilihat dari hasil deskripsi data di atas yang dapat dilihat pada gambar 1 .

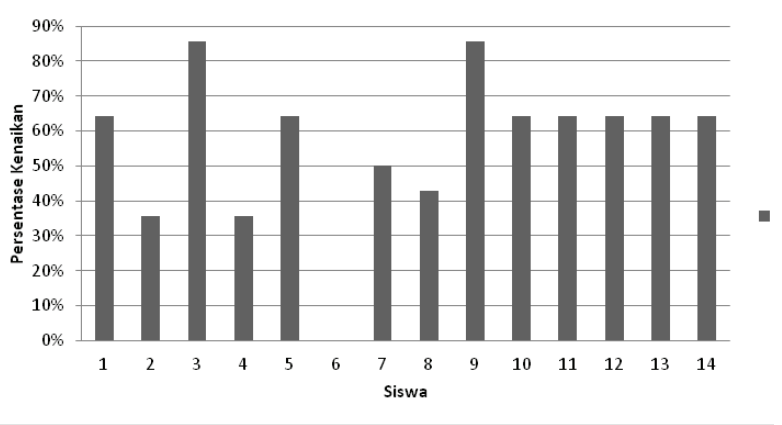

Gambar 1. Peningkatan Konsentrasi Anak Berkebutuhan Khusus Pada Materi Pembelajaran Sains dengan Menggunakan Metode Eksperimen

Berdasarkan hasil deskripsi data sebagaimana grafik peningkatan pada gambar 1, maka diperoleh persentase peningkatan konsentrasi anak berkebutuhan khusus pada materi pembelajaran sains dengan menggunakan metode eksperimen pada keseluruhan anak di kelas sebesar 56,1\%. Hal ini membuktikan bahwa metode eksperimen memberikan peningkatan pada konsentrasi anak berkebutuhan khusus, khususnya pada materi pembelajaran sains.

Data peningkatan hasil pre-tes dan post tes konsentrasi anak berkebutuhan khusus pada materi pembelajaran sains dengan mengunakan metode eksperimen dapat dilihat pada gambar 2 . 


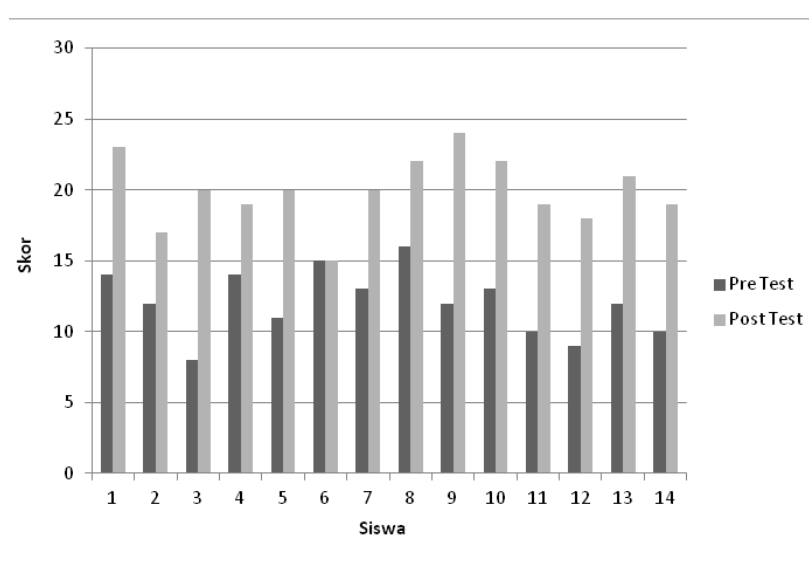

Gambar 2. Peningkatan Konsentrasi Anak Berkebutuhan Khusus Pada Materi Pembelajaran Sains dengan Menggunakan Metode Eksperimen Pre-Tes dan Post Tes

Persyaratan analisis yang harus dipenuhi agar analisis varians dapat dilakukan, yaitu melalui pengujian normalitas. Adapun deskripsi pengujian tersebut adalah sebagai berikut :

a. Uji Normalitas

Tujuan pengujian normalitas adalah untuk mengetahui apakah populasi penelitian berdistribusi normal atau tidak, sehingga jawaban yang diberikan responden dapat diproyeksikan sebagai jawaban yang mewakili seluruh populasi. Hal ini penting, karena jika ternyata data tidak berdistribusi normal, maka kelompok data tersebut tidak dapat dilakukan uji hipotesis dengan statistic parametrik.

Pengujian normalitas dalam penelitian ini menggunakan uji Liliefors. Pengujian dilakukan terhadap setiap kelompok data, yakni data tentang konsentrasi anak berkebutuhan khusus pada materi pembelajaran sains dengan menggunakan metode eksperimen. Dengan kriteria pengujian dengan menggunakan Liliefors adalah :

$\mathrm{H} 1$ diterima jika $\mathrm{L}_{\text {hitung }}<\mathrm{L}_{\text {tabel }}$

$\mathrm{H} 0$ diterima jika $L_{\text {hitung }}>L_{\text {tabel }}$

Berdasarkan hasil perhitungan diperoleh Lhitung $=0,13$, sedangkan Ltabel $=0,227$ pada taraf signifikasi $\alpha=0,05$ dan $n=14$. Hasil ini menunjukkan bahwa Lhitung kurang dari Ltabel. Dengan demikian dapat dikatakan bahhwa data yang diperoleh dari konsentrasi anak berkebutuhan khusus pada materi pembelajaran sains dengan menggunakan metode eksperimen berasal dari populasi yang berdistribusi normal.

\section{b. Pengujian Hipotesis}

Pada penelitian ini pengujian hipotesis dilakukan dengan menggunakan uji-t (satu pihak). Berdasarkan hasil perhitungan, $t_{\text {hitung }}$ sebesar 9,45 , dan $t_{\text {tabel }}$ dengan uji satu sisi pada taraf signifikansi 0,05 dengan $n-1=13$ adalah 1,77 , maka thitung $(9,45)>$ ttabel $(1,77)$. Hal ini berarti metode eksperimen memberikan pengaruh terhadap konsentrasi anak berkebutuhan khusus pada materi pembelajaran sains. (Khamidun\&Diana : 2012)

\section{Pembahasan}

Pengumpulan hasil data awal menunjukkan bahwa anak berkebutuhan khusus memiliki kemampuan awal yang masih rendah dalam berkonsentrasi pada kegiatan pembelajaran, terutama pembelajaran sains. Adanya peningkatan kemampuan konsentrasi tersebut dilakukan peneliti dengan memberikan sebuah perlakuan pada kelompok atau pada kelas anak berkebutuhan khusus yang berada pada satu kelas yang sama, serta kegiatan pembelajaran yang berkaiitan dengan pengenalan lingkungan (pembelajaran sains).

Pemberian perlakuan dengan menggunakan metode eksperimen sederhana bagi anak berkebutuhan khusus dilakukan selama 12 kali pertemuan. Hasil akhir yang didapat setelah diberikan perlakuan terlihat adanya peningkatan skor kemampuan konsentrasi anak berkebutuhan khusus pada materi kegiatan pembelajaran sains. Hasil pengujian hipotesis dengan menggunakan uji-t membuktikan bahwa kemampuan konsentrasi anak berkebutuhan khusus pada materi pembelajaran sains dengan menggunakan metode eksperimen memberikan pengaruh dan mengalami peningkatan signifikan. Hasil pengujian diperoleh thitung sebesar $9,45, t_{\text {tabel }}$ dengan uji satu sisi pada taraf signifikan 0,005 dengan $\mathrm{n}-1=13$ adalah 1,77, maka thitung $(9,45)>t_{\text {tabel }}(1,770)$ berarti metode eksperimen memberikan pengaruh yang signifikan terhadap konsentrasi anak berkebutuhan khusus pada pembelajaran sains.

Metode eksperimen yang dilakukan dalam pembelajaran sains pada anak berkebutuhan khusus merupakan metode eksperimen yang sangat sederhana. Hal ini mengingat kemampuan dan kketerbatasan yang dimiliki oleh setiap anak didalam kelas berbeda-beda (ada yanng tuna rungu, tuna grahita, autis, dan hiperaktif). Metode eksperimen yang dilakukan dalam pennelitian ini adalah dengan cara praktek langsung dalam melakukan kegiatan yang berkaitan dengan sains. Materi sain yang diberikan pada anak berkebutuhan khusus disini adalah materi yang masih sangat sederhana yang disesuaikan dengan kurikulum bagi anak berkebutuhan khusus. Materi yang diberikan berkaitan dengan pengenalan diri dan lingkungan dalam hal ini mengetahui nama temanteman di kelas dan guru yang dilakukan langsung pada setiap awal pertemuan. Selain itu juga pengenalan 
lingkungan anak dengan dilakukan melalui cerita yang dilakukan oleh guru dengan media buku gambar yang bertemakan binatang. Hal ini dikkarenakan kondisi anak yang tidak memungkinkan anak untuk banyak melakukan kegiatan diluar kelasdan jumlah guru yang terbatas dalam satu kelasnya. Pengenalan lingkungan anak diluar kelas dilakukan dua minggu sekali, seperti berjalan-jalan disekitar sekolah.

Selain itu juga materi pembelajaran sains yang diberikan berkaitan dengan pengelompokan dengan menggunakan media balok dan melakukan pemecahan masalah sederhana dengan menggunakan puzzle. Proses pembelajaran sains yang dilakukan pada anak-anak berkebutuhan khusus dengan metode eksperimen merupakan sebuah metode yang sangat sederhana dimana anak dapat mengenal dirinya dan lingkungan dan mampu mengendalikan dirinya didalam kelas dalam hal ini melatih konsentrasi anak agar dapat fokus pada kegiatan. Materi pembelajaran sains ini juga disesuaikan dengan tahap perkembangan anak berkebutuhan khusus diawal masuk sekolah yang masih membutuhkan penyesuaian lingkungan. Dengan metode eksperimen yang sangat sederhana ini ternyata dapat memberikan pengaruh terhadap konsentrasi anak- anak dalam kelas.

\section{PENUTUP}

\section{Kesimpulan}

Berdasarkan hasil temuan di atas maka kesimpulan yang diperoleh dalam penelitian ini adalah sebagai berikut : pengujian dengan menggunakan uji-t yang telah dilakukan dalam membuktikan hipotesis yang menyatakan bahwa metode eksperimen dapat memberikan pengaruh terhadap konsentrasi anak berkebutuhan khusus pada materi pembelajaran sains. Hal ini dibuktikan dengan hasil pengujian diperoleh thitung sebesar 9,45, ttabel dengan uji satu sisi pada taraf signifikan 0,005 dengan $\mathrm{n}-1=13$ adalah 1,77 , maka thitung $(9,45)>$ ttabel $(1,770)$ berarti metode eksperimen memberikan pengaruh yang signifikan terhadap konsentrasi anak berkebutuhan khusus pada pembelajaran sains. (Khamidun\&Diana : 2012)

Metode eksperimen sebagai salah satu metode pembelajaran yang digunakan di dalam kelas pra sekolah dalam hal ini di lembaga PAUD dapat memberikan pengaruh terhadap kemampuan anak dalam menerima materi kegiatan. Hal ini juga dapat dilakukan di kelas PAUD yang memiliki anak-anak berkebutuhan khusus. Adanya metode eksperimen yang dilakukan secara sederhana dapat meningkatkan konsentrasi bagi anak-anak yang memiliki kebutuhan khusus, khususnya pada materi kegiatan sains permulaan pada anak-anak berkebutuhan khusus, yang masih memerlukan pemahaman dan konsentrasi dalam mengenal diri dan lingkungannya.

\section{Saran}

Berdasarkan simpulan yang telah diuraikan diatas, maka dapat dikemukakan beberapa saran. Pertama, bagi guru khususnya guru PAUD di taman latihan dan observasi sekolah luar biasa kota Semarang, hendaknya dapat memberikan suasana pembelajaran yang lebih menyenangkan dan menarik dengan menggunakan berbagai metode pembelajaran yang dapat diberikan untuk anak-anak berkebutuhan khusus, khususnya metode eksperimen. Karena dengan metode ini anak akan mendapatkan pengelaman secara langsung baik dengan dirinya maupun dengan lingkungannya.

Kedua, diharapkan guru hendaknya dapat memberikan beragam materi kegiatan yang menarik, khususnya pada materi pembelajaran sains untuk anak-anak berkebutuhan khusus. Dengan anak dapat dapat menjadikan lingkungan sebagai sumber belajar, anak juga lebih dapat menghargai dan menyayangi terhadap semua makhluk hidup terutama dengan teman sebayanya.

Ketiga, kepada peneliti yang berminat untuk melakukan penelitian serupa disarankan untuk mempelajari terlebih dahulu tentang bagaimana mengkondisikan anak didalam kelas berkebutuhan khusus yang memiliki keberaggaman hambatan, sehingga dalam penelitian nantinya penguasaan materi dan kelas dapat menjadi hak peneliti sepenuhnya.

\section{DAFTAR PUSTAKA}

Djamarah, S. B. (2000). Belajar dan pembelajaran. Bandung: Remaja Rosdakarya.

Djamarah. (2002). Teori belajar dan pembelajaran. Jakarta: Djanbatan.

Eliason, C. (2009). A practical guide to early childhood curriculum 8th edition. PEARSON: Merril

\section{Prentice Hall}

Khamidun, D. (2012). Pengaruh metode pembelajaran eksperimen terhadap konsentrasi anak berkebutuhan khusus dalam materi pembelajaran sains di taman latihan dan observasi SLB Negeri Semarang. Semarang : Universitas Negeri 


\section{Semarang}

Kiranawati. (2008). Kegiatan pembelajaran dan pemilihan media pembelajaran. Diakses dari situs http://gurupkn.wordpress.com/2008/01/17/ kegiatan-pembelajaran-dan-pemilihan-mediapembelajaran/ pada tanggal....

Nugraha, A., Dwiyana, A.Sy. Ali Nugraha, A.Sy. Dina Dwiyana (Editor). (2008). Pengembangan Pembelajaran Sain Pada Anak Usia Dini. JIL SI Foundation.

Palendeng (2003). Teori dan metode pembelajaran. Bandung: Falah Proction.

Parwoto. (2007). Strategi pembelajaran anak berkebutuhan khusus. Jakarta: Departemen Pendidikan Nasional Direktorat Jenderal Pendidikan Tinggi.
Semiawan, R. C., \& Djeniah, A. (2002). Belajar dan pembelajaran dalam tahap usia dini. Jakarta: PT. Prenhallindo.

Smith, J. D. (2009). Inklusi "sekolah ramah untuk semua". Bandung: NUANSA.

Soekamto, T., \& Saripudin, W. U. (1997). Teori belajar dan metode-metode pembelajaran. Jakarta: PTU-PPAI UT.

Sullivan, J.,\& Gould, P. (1999). The inclusive early childhood classroom. Beltsville, Maryland: Gryphon House.

Sunaryo, S. (2007). Intervensi dini anak berkebutuhan khusus. Jakarta: Departemen Pendidikan Nasional Direktorat Jenderal Pendidikan Tinggi. 